
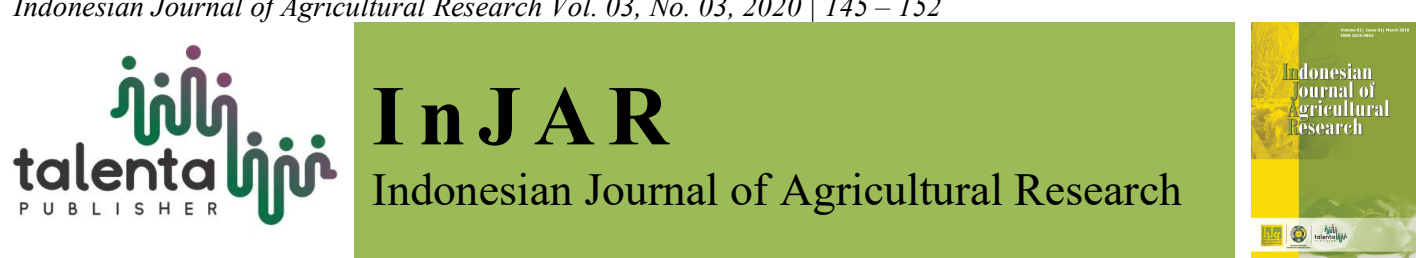

\title{
The Effect of Garlic (Allium sativum) Extract Pesticides in Repelling Rice Eating Bird Pests
}

\author{
Muhammad Yusril Hardiansyah $^{1^{*}}$, Arif Fikri Al Ridho ${ }^{1}$, Nurhidayat ${ }^{2}$ \\ ${ }^{1}$ Departement of Agronomy, Faculty of Agriculture, Hasanuddin University, Makassar, Indonesia \\ ${ }^{2}$ Departement of Soil Science, Faculty of Agriculture, Hasanuddin University, Makassar, Indonesia
}

\begin{abstract}
One of the main problems in rice cultivation is the difficulty of controlling bondol bird (Lonchura punctulata) pest attacks. Bird pest is one of the main enemies of farmers that can reduce crop production. Increasing bird populations cause crop yields to decline. So that one way that can be used in repelling bird pests is by giving pesticides from garlic extract. Allicin is a compound that gives garlic its distinctive smell which repels bird pests. This study aims to determine the effect of the provision of plant-based pesticides from garlic extract in repelling rice-eating bird pests. This research was conducted in Tonasa Village, Takalar District, South Sulawesi, Indonesia. Research implementation methods include the manufacture and testing of pesticides liquid extracts of garlic and application in the field by spraying, this spraying is carried out in the morning, afternoon, and evening before making the observations. Observation parameters use the method of comparing initial observations and final observations observed in the morning, afternoon and evening (comparison method) by conducting initial data collection (without using pesticides) and final data collection (after spraying pesticides), the average number of groups of birds that attack $1 \mathrm{Ha}$ of rice fields. The results obtained on average indicate quite a lot of attacks in a day, especially in the morning. After the use of the automatic repellent method the attacks of bondol bird groups tend to decrease where in the morning ratio of 20 to 33 decreases to 5 to 13 attacks, while the ratio of daytime 8 to 15 decreases to 3 to 7 attacks and the ratio of the evening 19 to 33 decreases to 6 to 12 bird group attacks. So that the administration of garlic extract pesticides is effective in reducing bird pest attacks.
\end{abstract}

Keywords: bird pest, garlic extract, pesticides, rice

Received 06 May 2020 | Revised 15 September 2020 | Accepted 07 November 2020

\section{Introduction}

Rice (Oryza sativa L.) is the main carbohydrate source for the majority of the population in Indonesia. This plant has become a strategic commodity in the Indonesian economy, so that lack of supply at a reasonable price is a threat to economic and political stability. Rice production is also the last defense in the Indonesian economy [1]. Data from the Government of Indonesia which targets rice production in 2016 is 80 million tons. This target is increasing compared to 2015 which was only able to produce 74.99 million tons [2]. The target is assumed due to the influence of el-nino and plant-disturbing organisms.

\footnotetext{
*Corresponding author at: Department of Agronomy, Agrotechnology Study Program, Faculty of Agriculture, Universitas Hasanuddin, Jl. Perintis Kemerdekaan KM.10, Makassar, Indonesia

E-mail address: yusrilhardiansyah1@gmail.com
} 
Various obstacles that arise in the process of rice cultivation can cause food security to waver. Since the last 10 years rice production in Indonesia has increased and in 2045 the Ministry of Agriculture is targeting Indonesia to become a world food barn, so as to maintain the stability of rice production in the next few years in supporting Indonesia to become a world food barn, it is necessary to anticipate early problems that arise in the process of rice cultivation. One of them is the difficulty of controlling rice-eating bird pests.

Bondol bird (Lonchura punctulata) pest is one of the main enemies of farmers that can reduce crop production. Increasing bird populations cause crop yields to decline. According to Salsabila [3], Bird pests consume an average of 5 grams of rice everyday. The attack of the bird group has troubled many farmers. The attack carried out by bird pests in the form of eating grains on rice panicles that have entered the period of cooking milk or rice with a planting period of 70 days. As a result of bird attacks rice production has decreased by $30-50 \%$. The attack occurred during shady weather conditions and birds attacking in groups [4]. The impact of the attack caused the rice to dry up and even empty seeds. This causes great unrest and loss for farmers.

Some types of birds that usually attack the rice crop area are sparrows, pekingese and bondol birds. The birds usually nest near the house, low trees or in the bushes around the fields. The biggest attack occurred by a sparrow attack. Sparrows always flock when they fly and eat rice, so if there are a lot of grains, they will eat a lot of rice. They are not just one day, but every day $[5]$.

Various methods used by farmers to prevent bird pests from attacking rice plants are by making a scarecrow or a rope which is tied at a certain distance so that the rope can be shaken can make a sound that is expected to be able to frighten bird pests. If this method does not work, it is not uncommon for farmers to jump directly into paddy fields to repel birds who perch on rice. Surely this method is very tiring and troublesome if done alone on a large rice field. When the rice plants have yellowed, usually farmers will be more active in taking care especially during critical hours, namely at $6-10$ in the morning and at $2-6 \mathrm{pm}$ is the time for the birds to look for food. Even because of the vast land some farmers employ people to look after the fields. This is seen from an economic perspective, this method is less effective and efficient because farmers have to pay additional fees to pay their wages [6].

Various methods used by farmers that are less effective can be overcome by using new technologies. One method that can be used in repelling bird pests is to use plant-based pesticides from garlic extract. The aroma of garlic (Allium sativum) can be used to dispel various pests in rice plants such as mice, birds, worms and so forth. Garlic contains elements of useful chemical compounds such as essential oils, alildisulfida and allisin, effective for repelling various pests. Allisin is a compound that gives a distinctive odor of garlic. According to [7], garlic extract can 
also function as an insect repellent. Compounds in allisin garlic, saponins, and flavonoids are chemicals that can function as insecticides, especially in eradicating pests and insects that are safe for health and the environment [8]. Garlic is also included in plant-based insecticides because the aroma of garlic is very pungent and the taste of hot and spicy garlic is thought to drive out various other nuisance animals such as worms the aroma [9].

This study aims to determine the effect of the provision of vegetable pesticides from garlic extract in repelling rice-eating pests. Information from the results of this study is expected to be a solution for farmers for a better rice cultivation process, especially in reducing the level of bird pest attacks.

\section{Materials and Methods}

This research was carried out in Paddinging, Tonasa Village, Sanrobone, Takalar Regency, South Sulawesi, Indonesia. This research was conducted in a period of three months, since September until December 2019. The tools used are blenders, knapsack sprayers, funnels, scales, measuring cups, filters, rulers, buckets, cameras and stationery. The ingredients used are garlic, water, labels and clear plastic. The steps for implementing the research are as follows:

\subsection{Manufacture and Testing of Plant Pesticides}

The process of making and testing of pesticides from garlic extract, includes:

a. Prepare tools and materials for pesticides to be used, including garlic as much as $5 \mathrm{~kg}$ per 15 liters of water.

b. Put on $5 \mathrm{~kg}$ garlic using a blender, then the results of the garlic dozing soaked in 15 liters of water and then allowed to stand for 5 days to get a better extract aroma.

c. After 5 days of immersion, the garlic soaking liquid results are then filtered using a filter to separate the water from the extracted pulp.

d. Put the garlic extract water into the knapsack sprayer tank using a funnel until it is full. Then the vegetable pesticides are ready to be applied.

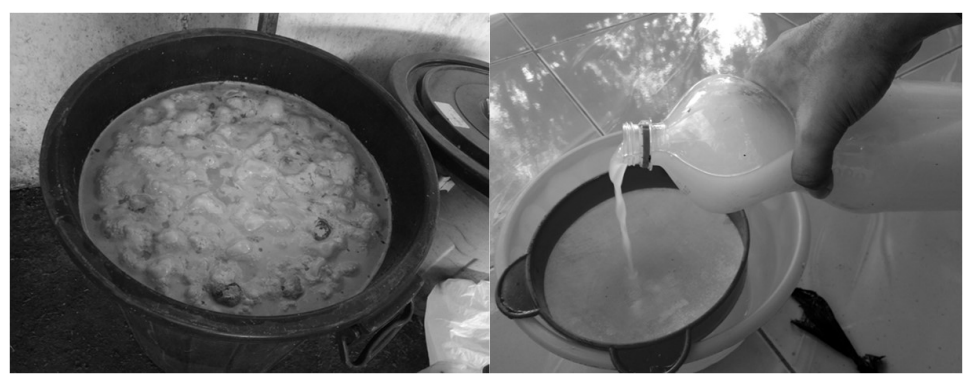

Figure 1. Immersion and Filtering of Pesticide Fluids 


\subsection{Spraying Method}

Spraying the garlic extract using a knapsack sprayer with a calibration method. Calibration is calculating or measuring the water requirements of a spray device for a certain area. Knapsack sprayer used in the form of a 15 liter tank using a polyjet nozzle with a size of 1.5 inches. Spraying was carried out on a 0.5 hectare $\left(5,000 \mathrm{~m}^{2}\right)$ paddy field area, whereas on a scale of 1 hectare $\left(10,000 \mathrm{~m}^{2}\right)$ a 30 liter tank can be used. The steps of the calibration method are filling the knapsack sprayer tank with 15 liters of garlic extract water. Next do the tank pump $10-15$ times until the air pressure in the tank is quite full. Then spray the area to be sprayed with the same speed and pressure until the garlic extract water runs out in the tank. The application or placement of paddy is carried out when the rice has entered the ripe phase of milk or before harvest, where the time of bird pests is very much attacking rice.

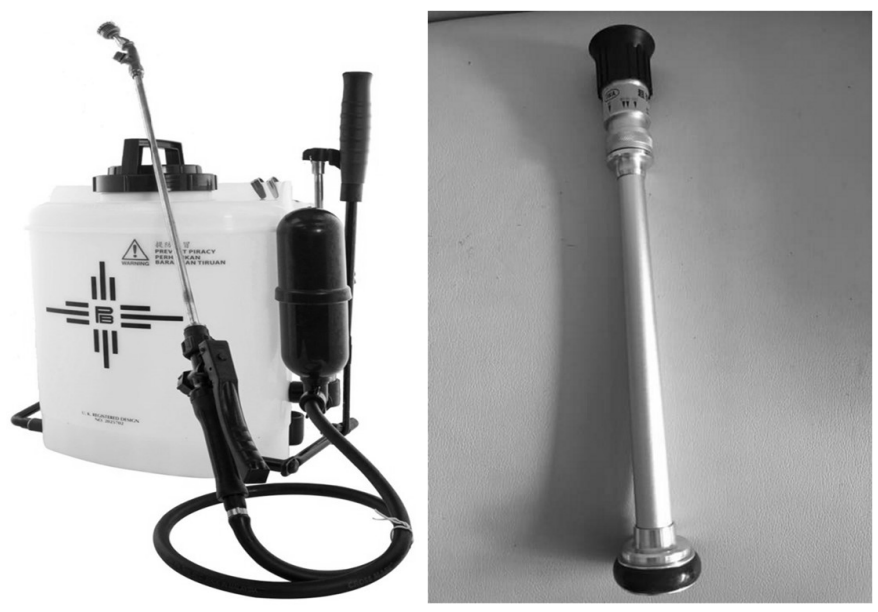

Figure 2. Knapsack Sprayer and Nozzle on Pesticide Spraying

\subsection{Observation Parameters}

Observations were made by comparing the initial observations and final observations (comparison method) [10], which included:

a. Initial observation, which are conducting preliminary data collection of how many average groups of bondol birds (Lonchura punctulata) that attack an area of $0.5 \mathrm{Ha}$ without using plant-based pesticides conducted with 3 observations namely at 06.00 a.m. to 08.00 a.m. (morning), 11.00 a.m. to 01.00 p.m. (afternoon), and 03.00 p.m. to 05.00 p.m. (evening). This observation is carried out during the paddy period before harvesting or at the age of 65100 days after planting and is carried out for 4 full days to obtain accurate average observation data.

b. Final observation, which is to collect the final data on how many average groups of bondol birds (Lonchura punctulata) that attack an area of $0.5 \mathrm{Ha}$ by using vegetable pesticides carried out by 3 times of spraying at 06.00 a.m. to 08.00 a.m. (morning), 11.00 a.m. to 01.00 p.m. (afternoon), and 03.00 p.m. to 05.00 p.m. (evening). This observation was carried out for 4 full days after making initial observations to obtain accurate average data. 


\section{Results and Discussion}

Observations made in this study lasted for 2 days. On the first day namely the initial observation or without spraying pesticides while on the second day namely the final observation by spraying pesticides. Observations were made at intervals of only one day in order to get the optimum phase of rice growth preferred by pests of birds other than that so that the time interval of the attacks of bondol birds pest groups did not occur so long. The comparison method is carried out in order to find out how many flocks of birds attacked before the tool is applied and when the tool is applied. The results obtained indicate that there is a significant difference between the initial observation and the final observation of the bird group attack.

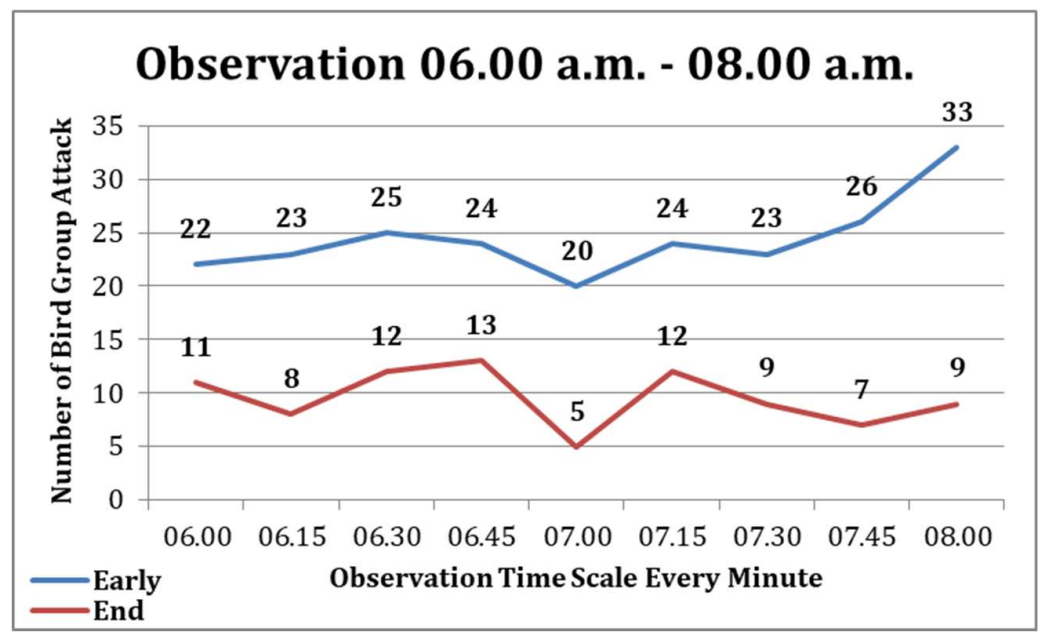

Figure 3. Comparison Chart of Observations Before (Early) and after (end) given pesticides extract of garlic at 06.00 A.M. To 08.00 A.M.

On the comparison of observations at 06.00 a.m. to 08.00 a.m. (morning) showed that the average group of bondol birds pests attack before being given garlic extract pesticides are as many as 20 to 33 groups of birds, but after being given this garlic extract pesticide at intervals of 2 hours after spraying, the average attack of bird pests decreased into 5 to 13 groups of birds (Figure 3). That is because morning and evening is a time of bird pest crisis in search of food so that very many bird pests that come. This is also in line with the statement of [6], which states that where when the rice plants have yellowed, usually farmers will be more active in taking care especially during critical hours, namely at $6-10$ am and $2-6 \mathrm{pm}$ is the time of birds looking for food.

In addition, the reduced level of attack by bird groups is attributed to the effect of spraying pesticides. Garlic extract contains beneficial chemical compounds, such as essential oils, alildisulfida and allisin, effective in repelling various pests, so it is very helpful and does not burden farmers in repelling pest attacks the bird. The effect of garlic on bird pests is that garlic gives a pungent aroma that is very disliked by bird pests because garlic contains chemical compounds that are toxic and very disliked by rice plant pests. This is supported by the opinion 
of [8], which states that the compounds in garlic allisin, saponins, and flavonoids are chemicals that can be used as insecticides, especially in eradicating pests and insects that are safe for health and the environment. Active compounds found in plants, especially garlic, have a high dose of toxicity.

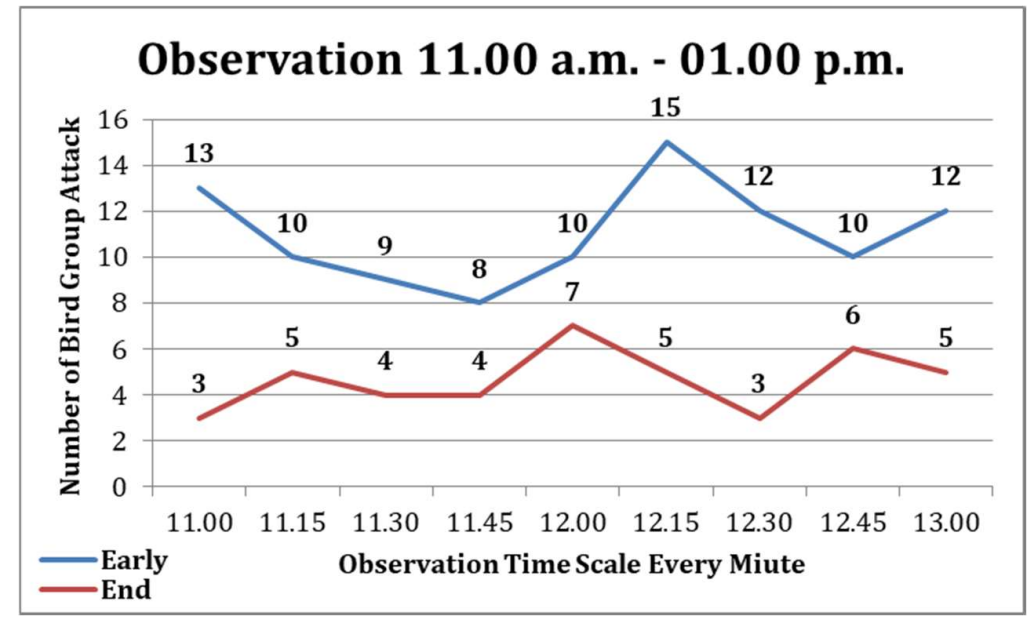

Figure 4. Comparison Chart of Observations Before (Early) and After (End) Given Pesticides Extract from Garlic at 11:00 a.m. to 01:00 p.m.

On the comparison of observations at 11:00 a.m. to 01:00 p.m. (afternoon) shows that the average group of bondol birds pests attack before being given garlic extract pesticides are as many as 8 to 15 groups of birds, but after being given this garlic extract pesticide at intervals of 2 hours after spraying, the average attack of bird pests decreased into 3 to 7 groups of birds (Figure 4). The number of bird pest attacks decreased according to the initial data collection compared to morning observations because during the day the pests of birds more often settle in the trees around the rice fields rather than looking for food, because the time of daylight is the time when the pests of birds do not look for food. In addition, when the weather is blazing in the afternoon the sun fades more often for an instant which makes the pests of birds prefer shady conditions or no sun to look for food [4] also stated that the attacks of ordinary bird groups attack in shady weather conditions and attack in groups. The presence of surrounding trees also helps these bird pests to nest a lot so that at any time will also attack rice simultaneously and clustered. In accordance with the opinion of [11], the existence of trees is important for the life of the group of bondol birds (Lonchura punctulata) and sparrows (Estrildidae), such as nesting sites, shelter and availability of food sources.

In comparison observations at 03:00 p.m. to 05:00 p.m. (evening) shows that the average group of bondol birds pests attack before being given garlic extract pesticides are as many as 19 to 33 groups of birds, but after being given this garlic extract pesticide at intervals of 2 hours after spraying, the average attack of bird pests decreased to 6 to 12 groups of birds (Figure 5). That is because in the afternoon the time for pests of birds is also looking for food, but in the afternoon the number of groups of birds that attack is not as much as the number of groups of birds in the 
morning because more pests and birds perch on the trees and fly in groups of one point to point. In addition, morning time is a favorite time for birds to attack due to environmental conditions that are more shady than afternoon or evening [12]. Therefore it is not uncommon for bird pests to tend to perch and take shelter in the trees around the rice fields when the sun is hot.

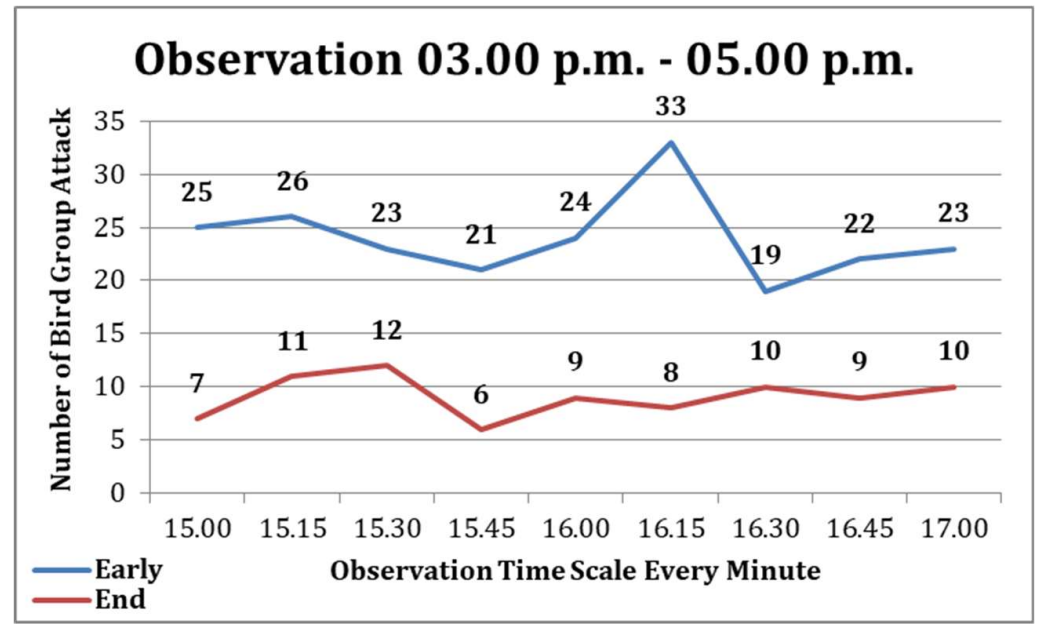

Figure 5. Comparison Chart of Observations Before (Early) and After (End) Given Pesticides Extract of Garlic at 03.00 p.m. to 05.00 p.m.

The attack of bird groups that experienced a significant decrease after being given a pesticide extract from garlic due to the aroma of garlic extract sprayed on the surface of leaves, ears, and rice panicles so that if there were pests that perched the birds would smell the pesticides which would then stay away, the aroma of this garlic extract liquid aroma can last for 2 - 3 hours if the sun is not hot (cloudy) and only lasts for about $1-2$ hours if the sun is very hot (bright), besides that the help of wind that shakes panicles and leaves also affects the spread of the scent of the liquid extract of garlic, so that pests of birds when inhaling the scent from far away conditions will immediately move to another place. Because birds have a strong sense of smell against various conditions. In accordance with the opinion of [13], that birds have a sense of smell and hearing that is very sharp so it is very difficult to be caught by hunters.

\section{Conclusion and Recommendation}

\subsection{Conclusion}

Evaluation of bondol birds pest attacks on rice plants on average shows quite a lot of attacks in a day, especially in the morning. After being given the pesticide extract, the attack of the bird group tends to decrease quite significantly where in the morning ratio of 20 to 33 it decreases to 5 to 13 attack of the bird group, while the ratio of daytime 8 to 15 decreases to 3 to 7 attack of the bird group and the evening comparison 19 up to 33 decreased to 6 to 12 attacks by bird groups. So that the administration of garlic extract pesticides is effective in reducing bondol birds pest attacks. 


\subsection{Recommendation}

It is expected that farmers, especially rice farmers, use natural-based methods and do not damage plants in repelling bird pests. The use of vegetable pesticides from garlic extract is one of the right solutions and can be applied by farmers in repelling bird pests so that it is very safe and does not incur expensive costs in its application.

\section{Acknowledgment}

Thank you to the Ministry of Research and Higher Education (Kemenristekdikti) for providing full support to the writer and Hasanuddin University in terms of funding and facilities in the process of conducting research. Thank you was also conveyed to the Faculty of Agriculture, Hasanuddin University (UNHAS), which provided full support from the beginning to the end of the activity.

\section{REFERENCES}

[1] B. Amang and M. H. Sawit, Kebijakan Beras dan Pangan Nasional: Pelajaran dari Orde Baru dan Orde Reformasi. Bogor: IPB Press, 2001.

[2] Statistics Indonesia, Statistical Yearbook of Indonesia 2018. Jakarta, 2018.

[3] A. Salsabila, Burung-Burung Pintar dan Unik. Padang: Universitas Andalas, 1991.

[4] K. Ziyadah, "Kemampuan makan, preferensi pakan, dan pengujian umpan beracun pada bondol peking (Lonchura punctulata L.) dan bondol jawa (Lonchura leucogastroides Horsfield \& Moore)," Skripsi, Institut Pertanian Bogor, Indonesia, 2011.

[5] A. S. Modjo, "Rancang bangun alat pengendali hama burung pemakan bulir padi sawah (Oryza Sativa L.) sistem mekanik elektrik," Universitas Negeri Gorontalo, 2012.

[6] Syahminan, "Prototype pengusir burung pada tanaman padi berbasis mikrokontroler aurdino," J. Spirit, vol. 9, no. 2, pp. 26-34, 2017.

[7] S. D. Desvani, L. Ich, Aisyah, M. Roifatul, and W. Naila, "uji efektivitas pestisida nabati ekstrak bawang putih (Allium sativum) dan biji mahoni (Swietenia mahagoni) untuk menurunkan populasi hama wereng batang coklat (Nilaparvata Lugens) pada tanaman padi," Surakarta, 2015.

[8] D. S. Kuswardhani, Sehat Tanpa Obat dengan Bawang Merah dan Bawang Putih. Yogyakarta: Rapha Publishing, 2016.

[9] D. Sulistyoningsih, B. Santosa, and D. Sumanto, "Efektivitas larutan bawang putih dalam membunuh larva Aedes aegypti," J. Kesehat., vol. 2, no. 2, 2009.

[10] S. Wirdayanti, Analisis Data Eksploratif (Analisis Compare Means). Yogyakarta: Universitas Islam Indonesia, 2013.

[11] S. C. Kendeigh, "Analysis of losses in the nesting of birds," J. Wildl. Manage., vol. 6, no. 1, pp. 19-26, 1942.

[12] A. Ardjansyah, J. B. Hernowo, and S. Priambodo, "The influences of bondol attack against paddy damage in Bogor," Media Konserv., vol. 22, no. 2, pp. 101-110, 2017.

[13] R. Rudiansyah and M. Radhi, "Perilaku satwa liar pada kelas burung (aves)," OSF Preprints, 2019. 